\title{
Factors associated with 56-day non-return rate in dairy cattle
}

\author{
Ramiro Fouz ${ }^{(1)}$, Fernando Gandoy(1), María Luisa Sanjuán ${ }^{(2)}$, Eduardo Yus ${ }^{(2)}$ and Francisco Javier Diéguez ${ }^{(3)}$
}

(1)Africor Lugo, Ronda de Fingoi, 117, 27002, Lugo, Spain. E-mail: xerencia@africorlugo.com, info@africorlugo.com (2)Universidade de Santiago de Compostela (USC), Facultade de Veterinaria de Lugo, Instituto de Investigación e Análises Alimentarias, Unidade de Epidemioloxía e Sanidade Animal, Campus Universitario, 27002 Lugo, Spain. E-mail: marisa.sanjuan@usc.es, eduardo.yus@usc.es (3)USC, Facultade de Veterinaria de Lugo, Departamento de Anatomía e Produción Animal. E-mail: franciscojavier.dieguez@usc.es

Abstract - The objective of this work was to identify factors associated with the 56-day non-return rate (56-NRR) in dairy herds in the Galician region, Spain, and to estimate it for individual Holstein bulls. The experiment was carried out in herds originated from North-West Spain, from September 2008 to August 2009. Data of the 76,440 first inseminations performed during this period were gathered. Candidate factors were tested for their association with the 56-NRR by using a logistic model (binomial). Afterwards, 37 sires with a minimum of 150 first performed inseminations were individually evaluated. Logistic models were also estimated for each bull, and predicted individual 56-NRR rate values were calculated as a solution for the model parameters. Logistic regression found four major factors associated with 56-NRR in lactating cows: age at insemination, days from calving to insemination, milk production level at the time of insemination, and herd size. First-service conception rate, when a particular sire was used, was higher for heifers $(0.71)$ than for lactating cows $(0.52)$. Non-return rates were highly variable among bulls. A significant part of the herd-level variation of 56-NRR of Holstein cattle seems attributable to the service sire. High correlation level between observed and predicted 56-NRR was found.

Index terms: dairy cattle, logistic models, reproductive performance, sire influence.

\section{Fatores associados à taxa de não retorno em 56 dias em bovinos leiteiros}

Resumo - O objetivo deste trabalho foi identificar fatores associados com a taxa de não retorno de 56 dias (56-TNR) em rebanhos leiteiros na região da Galícia, Espanha, e estimá-las individualmente para touros da raça Holandesa. O experimento foi realizado em rebanhos do Noroeste da Espanha, entre setembro de 2008 e agosto de 2009. Recolheram-se dados das 76.440 primeiras inseminações realizadas durante este período. Foram avaliados os possíveis fatores candidatos quanto à sua associação com 56-TNR por meio de um modelo logístico (binomial). Posteriormente, 37 touros com um mínimo de 150 inseminações realizadas foram avaliados individualmente. Os modelos logísticos foram estimados também para cada touro, e os valores preditos de 56-TNR foram calculados como solução dos parâmetros do modelo. A regressão logística encontrou quatro fatores principais associados a 56-TNR em vacas lactantes: idade à inseminação, período do parto à inseminação, produção de leite no momento da inseminação e tamanho do rebanho. A taxa de prenhez à primeira inseminação, quando um touro particular foi utilizado, foi maior em novilhas $(0,71)$ do que em vacas lactantes $(0,52)$. Os valores da taxa de não retorno foram altamente variáveis entre touros. Uma proporção significativa da variação, no rebanho, de 56-TNR em touros de raça Holandesa é imputável ao touro. Foi encontrada uma alta correlação entre os valores observados e estimados para 56-TNR.

Termos para indexação: bovinos leiteiros, modelos logísticos, desempenho reprodutivo, efeito paterno.

\section{Introduction}

Low fertility of dairy herds is one of the most frequent reasons for culling (Rocha et al., 2001). Selection for milk yield and its negative genetic correlation with fertility traits has resulted in a downward genetic trend in the fertility of dairy cows (Wall et al., 2003; Pryce et al., 2004).

The reproductive performance of a dairy herd has a significant effect on its profitability, since reproduction problems are followed by extra inseminations and veterinary treatment costs, prolonged calving intervals and greater rates of involuntary culling. To improve, or at least slow, the deterioration in fertility, more emphasis on this trait must be put during selection (Van Doormaal et al., 2007). Insemination outcome depends on both female and male fertility, and determining which parameters to include in genetic evaluation is difficult. 
The non-return rate (NRR) is defined as the proportion of cows that are not subsequently re-bred within a specified period of time after an insemination. It can be adopted as an indirect indicator of fertility, and data can be quickly obtained at a reasonable collecting cost (Miglior et al., 1997). Cow fertility changes with age, often depending on previous performance (Jansen et al., 1987), environmental factors, such as herd management and temperature and humidity conditions, feeding practices or semen handling. Furthermore, the physiological status of virgin heifers is quite different from that of milking cows because stress from lactation and calving affects fertility traits (Miller et al., 2001).

In this context, male fertility is also essential for cattle breeders, and they require means to select sires efficiently (Averill et al., 2004). Despite of the low heritability estimates for reproductive traits (Pryce et al., 2004), and the fact that it could be biased by environmental factors, studies suggest that some genetic variation exists that can potentially be used to improve reproductive performance or at least avoid its further deterioration through adequate bull choice (Averill et al., 2004). Non-return rate is the most frequently used measure for male fertility, and bull evaluations for this trait have been officially published in the main cattle farming areas. Models for evaluating service sires for NRR have been studied by performing test inseminations in the field or assessing the penetration ability of spermatozoa (Taş et al., 2007; Van Doormaal et al., 2007; Africor-Lugo, 2009; Norman et al., 2009). Non-return rate is less biased by selection, as compared to other fertility traits (Andersen-Ranberg et al., 2005), and may be used as a reliable indicator of the expression of bull fertility if the causes that influence it can be controlled (Miglior et al., 1997; Al Naib et al., 2011), when the accuracy of data collection is high.

Assessment of bulls by means of NRR is an efficient tool when reproductive efficiency decreases (Clay \& McDaniel, 2001). Bulls vary in conception rates, and these data have been estimated and successfully used, fundamentally at 56 days post-insemination (56-NRR) (Andersen-Ranberg et al., 2005; Jamrozik et al., 2005; Van Doormaal et al., 2007; Sun et al., 2009). However, no comprehensive study assessing this parameter from the same dataset has been published (Eghbalsaied, 2011). Strong favourable genetic correlations between NRR and other reproductive traits, in both heifers and cows, pointed out that current inclusion of this trait in selection decisions could highly represent most of fertility traits (Eghbalsaied, 2011). A method aimed to provide farmers and veterinaries with detailed information about NRR, together with a measure of their accuracy, would be an important tool for reproductive and genetic programs.

Galicia is the major cattle-farming region of Spain. It is responsible for 35\% of the milk produced in Spain, constituting approximately $1.7 \%$ of the milk produced in the European Union. Decline in female fertility in this area, related to high milk production, has led to more emphasis on sire evaluations.

The objective of this work was to identify factors associated with the 56-day non-return rate (56-NRR) in dairy herds in the Galician region, Spain, and to estimate it for individual Holstein bulls.

\section{Materials and Methods}

Information was recorded from the Official Milk Recording system (AFRICOR-LUGO, 2009). Only records from Holstein dairy cows were used. The data of insemination performed with Holstein semen in the area during the period between September 1, 2008, and August 31, 2009, were gathered (76,440 records performed with Holstein doses; 19,354 were virgin heifers). For each inseminated cow, the following data were collected: insemination date, in order to evaluate possible influence of heat stress on fertility; age at the time of insemination; days from previous calving to insemination; previous calving difficulty; milk daily production at insemination; and size of the herd where the cow remains. These variables were evaluated as dependant variables for their influence on 56-NRR. Cows subjected to hormonal fertility treatment (i.e. synchronization strategies) were excluded. Descriptive analysis of the cows surveyed is shown in Table 1.

The 56-NRR obtained for Holstein sires were also compared with data from cows inseminated with semen from different bull breeds (Limousine, Belgian Blue-White and Rubia Gallega - autoctonous breed from the Northwest Spain), since $16.9 \%$ of the first inseminations performed in Galician Holstein cows, during the experimental period, used beef bulls for mating. Holstein bulls, with a minimum of 150 insemination records and worldwide diffusion, were identified for their individual evaluations of 56-NRR after first service. Mean number of the first insemination 
records for these bulls was 300.10 (84.42 for virgin heifers, 166.49 for lactating cows). For insemination, semen packed into plastic straws and stored in liquid nitrogen at $-196^{\circ} \mathrm{C}$ was used, holding $0.50 \mathrm{~cm}^{3}$ of semen. Each straw contained around 10-15 million spermatozoa.

Regarding analysis, candidate variables were tested for their association with the 56-NRR by using a logistic model (binomial). Models were constructed introducing possible combinations of predicting variables (and first order interactions) until those that best explained the variance in the dependent variable (56-NRR) could be selected. Robust estimates of variance were applied to make adjustments within herd cluster effects. Nonreturn rate was defined as a binary trait, on the basis of whether $(=1)$ or not $(=0)$ the insemination had conceived the mate. The 56-NRR for individual bulls after first service was estimated with $95 \%$ confidence level. Error of the estimations, provided as measure of accuracy, was calculated as,

$$
\left[\left(Z_{\alpha / 2} \mathrm{p} \mathrm{q} /\left(\mathrm{n}^{\prime}\right)^{0.5}\right)\right] 100,
$$

in which: $Z_{\alpha / 2}$ is 1.96 , for a $95 \%$ confidence level; $p$ is the expected NRR for each bull ( 0.5 for a conservative estimation procedure); $\mathrm{q}$ is 1 - $\mathrm{p}$; and $\mathrm{n}$ ' is determined by $n^{\prime}=n(1+\rho(m-1)$, in which $n$ is the original sample size (number of first insemination records for each bull), $\rho$ is the intra-cluster (intra-herd) correlation coefficient, and $\mathrm{m}$ is the mean number of records per herd for each bull.

Logistic models were also estimated for individual bulls, and predicted individual 56-NRR values were calculated as solution of the model when model parameters were applied to a mean cow, as indicated in Table 1.

\section{Results and Discussion}

The logistic regression model found four major factors associated with the 56-NRR in lactating cows: age at insemination, days from previous calving to insemination, daily milk production level at the time of insemination and herd size. Previous calving difficulty and season of insemination were not significantly related to this parameter. Furthermore, 56-NRR slightly decreased when age, production level at insemination and herd size increased. Otherwise, it increased as days from previous calving to insemination increased (Table 2).

Only age at the time of first insemination seemed to be associated with 56-NRR in nulliparous heifers. There was a trend for 56-NRR to be greater on older heifers,

Table 1. Descriptive analysis of the surveyed cows.

\begin{tabular}{|c|c|c|c|c|c|c|}
\hline \multirow[t]{2}{*}{ Parameter } & \multicolumn{3}{|c|}{ Lactating cows } & \multicolumn{3}{|c|}{ Nulliparous heifers } \\
\hline & Mean & $95 \% \mathrm{CI}$ & Median & Mean & $95 \% \mathrm{CI}$ & Median \\
\hline Age at insemination (months) & 55.30 & $55.12-55.49$ & 50 & 16.11 & $16.01-16.14$ & 16 \\
\hline Days from previous calving to insemination & 87.27 & $86.98-87.55$ & 79 & - & - & - \\
\hline \multicolumn{7}{|l|}{ Previous calving difficulty ${ }^{(1)}$} \\
\hline Easy calving (\%) & 72.79 & - & - & - & - & - \\
\hline Slight problems $(\%)$ & 24.20 & - & - & - & - & - \\
\hline Difficult calving (\%) & 2.41 & - & - & - & - & - \\
\hline Caesarean/fetotomy (normal) (\%) & 0.20 & - & - & - & - & - \\
\hline Abnormal presentation $(\%)^{(2)}$ & 0.40 & - & - & - & - & - \\
\hline Milk production level at artificial insemination & 32.85 & $32.78-32.92$ & 32 & - & - & - \\
\hline
\end{tabular}

${ }^{(1)}$ Categorical variables as codified by the Official Milk Recording (AFRICOR-LUGO, 2009). ${ }^{(2)}$ Including caesarean/fetotomy due to this problem. CI, 95\% confidence interval. Mean, 95\% CI and median of the herd size were 66, 65.58-66.41 and 49, respectively.

Table 2. Multivariate logistic regression model to evaluate factors related to 56-day non-return rates in lactating cows.

\begin{tabular}{|c|c|c|c|c|c|}
\hline Parameter & $\beta$ & p-value & $\beta$ exponential & $95 \%$ confidence interval & \\
\hline Age at insemination (months) & -0.001 & 0.009 & 0.999 & 0.999 & 1.000 \\
\hline No of cows in the herd & -0.001 & $<0.001$ & 0.999 & 0.998 & 0.999 \\
\hline Milking production at the time of insemination & -0.016 & $<0.001$ & 0.984 & 0.983 & 0.986 \\
\hline Previous calving-insemination interval & 0.004 & $<0.001$ & 1.004 & 1.004 & 1.005 \\
\hline Intercept & 0.367 & $<0.001$ & 1.443 & - & - \\
\hline
\end{tabular}


but the difference was not significant $(p=0.059)$. The observed effect of age on conception was different for nulliparous heifers and cows. Malhi et al. (2007) suggested that reduced developmental competence of oocytes from older cows could explain the decreased fertility observed in elder dams. Multiple calving with age is also related with delayed involution and declining uterine conditions for consecutive pregnancies, and represent major risks for poor postpartum fertility (Berglund, 2008). However, older heifers that bred for the first time had a slightly higher rate of success for the first insemination (56-NRR), smaller number of services, shorter gestations, and smaller calves in both first and later parities (Jamrozik et al., 2005). Older heifers are more likely to attain the target body height and weight for artificial insemination (AI), although too late insemination may also be responsible for the failure of AI, since heifers probably will have reduced fertility related to over-fat condition (Mekonnen et al., 2010). Nonetheless, in the present study, the older heifer was inseminated at 20 months of age.

Calving to first insemination describes the ability of a cow to show estrus, while the NRR is related to the capacity of a cow to conceive when inseminated (Ben Jemaa et al., 2008). This interval includes the average days lost by the voluntary and involuntary waiting periods. When the voluntary waiting period is short, the first conception rate can be lower. Post-partum negative energy balance is the most powerful factor in the inhibition of normal ovarian activity, especially if the body condition score of the cow is not adequate.

Conception rates improve as post-partum period passes, and cow recovers equilibrium, which allows for normal follicular growth and maturation (Bastin et al., 2010).

Increasing milk production level was also related to a reduced 56-NRR (Table 2). Selection process for milk yield increases blood concentrations of somatotropin and prolactin, stimulators of lactation, and decreased insulin, a hormone that is antagonistic to lactation and may be important for normal follicular development (LeBlanc, 2010). Therefore, reproductive performance is compromised primarily through delayed ovarian activity and also reduced conception rates by high milk yield. An interaction between calving to first insemination interval and milk yield was expected to exist, but could not be observed in the present study. The effect of milk yield on 56-NRR should be different for cows with different calving-first insemination intervals. No collinearity problems were detected between other variables.

Data also indicates that large herds are more inclined to worsen 56-NRR (Table 2). It could be indirectly related to closer observation of cows, which is easier in smaller herds and result in a variability reduction of the interval between the onset and the estrus observation. Therefore, cows are more likely to be inseminated at the optimum time, improving reproductive performance (Pursley et al., 1998). Large herds have a greater number of AI than small herds (Löf et al., 2007). Herd size is also related to the management system and can be a useful additional information to make inferences about herd reproductive performance.

In case of heat stress, animals reduce both production and reproduction in order to adapt to the environment. The warmest month during the survey was June 2009, with mean maximum temperatures ranging from 19 $23^{\circ} \mathrm{C}$, and mean relative humidity $(\mathrm{RH})$ from $62-91 \%$ (Meteogalícia, 2010). Upper critical temperatures for lactating cows can be as low as $24-27^{\circ} \mathrm{C}$, with high RH (Morton et al., 2007). These temperatures could be reached inside the farms only occasionally. Probably, this is the reason for the lack of evidence for the association between 56-NRR and heat stress in the present study. Nevertheless, other works showed that environmental heat stress should not have a significant negative impact on conception in Holstein heifers (Roth, 2008).

Dystocia was associated with reproductive tract abnormalities, which reduce fertility (Berglund, 2008). Only $0.60 \%$ of the previous calving registered for the surveyed cows required surgical interventions (as caesarean or fetotomy) and, perhaps, the importance of this factor could not be fully clarified. However, results indicate that in the absence of major interventions, there were no differences between easy, slightly problematic or difficult calving in terms of success in the subsequent insemination.

The 56-NRR means observed in the present study, with inseminations performed with Holstein doses, were 0.71 for virgin heifers and 0.52 for cows. Nonreturn rate derived from inseminations done in the same period using semen from other breeds, for nulliparous heifers/milking cows, were respectively: 0.71/0.58, for Limousin; 0.75/0.52, for Belgian Blue-White; and $0.81 / 0.61$, for Rubia Gallega. Lately, there has been an increased interest in crossbreeding dairy breeds, mainly due to low milk price in several countries, which has 
forced producers into using more beef sires to generate valuable beef cross calves, or due to insemination of Neospora/paratuberculosis-seropositive cows with beef bull semen to reduce the risk of rearing unhealthy heifers (Sørensen et al., 2008). Knowing the potential fertility of possible crosses to be performed is an important factor to consider prior to the election of a particular breed. As expected, the 56-NRR of heifers and primiparous cows was higher than that of multiparous ones (Jamrozik et al., 2005; Soydan et al., 2009; Eghbalsaied, 2011).
The 56-NRR estimates were highly variable among different sires, both for nulliparous heifers and lactating cows (Table 3). Mean number of sire insemination records per herd was low and there was little clustering within herds. These results seem to indicate that a significant part of the herd-level variation of 56-NRR in Holstein cattle is attributable to the service sire. When logistic models were estimated for each bull, observed and predicted NRR values were quite similar, showing a high correlation level. Taking this into account, and despite the possible influence of other factors, which

Table 3. Fifty six-day non-return rate estimations for individual Holstein bulls ${ }^{(1)}$.

\begin{tabular}{|c|c|c|c|c|c|c|c|c|c|}
\hline \multirow[t]{2}{*}{ Bull name } & \multicolumn{4}{|c|}{ Nulliparous heifers } & \multicolumn{5}{|c|}{ Cows } \\
\hline & $\mathrm{N}$ & $\mathrm{h}$ & NRR & e $(\%)$ & $\mathrm{N}$ & $\mathrm{h}$ & NRR & pNRR & $\mathrm{e}(\%)$ \\
\hline Cerettese Yoriko Tl Tv & 54 & 25 & 0.78 & 13.34 & 183 & 72 & 0.46 & 0.46 & 7.24 \\
\hline Picston Shottle & 885 & 230 & 0.68 & 3.29 & 357 & 132 & 0.52 & 0.49 & 5.19 \\
\hline Jelder T1 Tv & 143 & 61 & 0.76 & 8.19 & 207 & 89 & 0.56 & 0.54 & 6.81 \\
\hline Ladino Park Talent Imp & 745 & 262 & 0.73 & 3.59 & 815 & 307 & 0.53 & 0.52 & 3.43 \\
\hline Lajeante Kingly & 132 & 40 & 0.90 & 8.53 & 78 & 31 & 0.45 & 0.52 & 3.43 \\
\hline Charpentier Magot & 82 & 53 & 0.71 & 10.82 & 331 & 111 & 0.50 & 0.49 & 5.39 \\
\hline Comestar Lheros & 14 & 13 & 0.57 & 26.19 & 346 & 149 & 0.52 & 0.52 & 5.27 \\
\hline Persuit September Storm & 248 & 81 & 0.77 & 6.24 & 382 & 127 & 0.46 & 0.45 & 5.02 \\
\hline Granduc Tribute & 72 & 41 & 0.75 & 11.55 & 165 & 62 & 0.50 & 0.50 & 7.64 \\
\hline Calbrett-i H H Champion & 86 & 40 & 0.74 & 10.57 & 116 & 49 & 0.54 & 0.53 & 9.11 \\
\hline Cedarwal Spirte TL TV & 300 & 122 & 0.67 & 5.66 & 304 & 113 & 0.40 & 0.40 & 5.63 \\
\hline Braedale Goldwyn & 274 & 89 & 0.85 & 5.93 & 52 & 36 & 0.60 & 0.58 & 13.59 \\
\hline Jusaba Lex & 39 & 31 & 0.74 & 15.69 & 163 & 81 & 0.58 & 0.58 & 7.68 \\
\hline Fustead Emory Blitz & 144 & 67 & 0.76 & 8.17 & 290 & 124 & 0.49 & 0.51 & 5.76 \\
\hline Roylane Jordan & 139 & 44 & 0.73 & 8.33 & 155 & 43 & 0.57 & 0.57 & 7.89 \\
\hline Alpag Iron Active & 114 & 57 & 0.58 & 9.18 & 132 & 66 & 0.36 & 0.30 & 8.53 \\
\hline Askew Reece & 53 & 21 & 0.62 & 13.47 & 152 & 35 & 0.49 & 0.50 & 7.99 \\
\hline R-E-W Buckeye & 1,886 & 607 & 0.70 & 2.26 & 1,335 & 501 & 0.49 & 0.49 & 2.69 \\
\hline Sildahl Airraid & 517 & 166 & 0.71 & 4.32 & 545 & 191 & 0.50 & 0.51 & 4.21 \\
\hline Sandy-Valley Bolton & 379 & 200 & 0.66 & 5.03 & 2,107 & 627 & 0.46 & 0.47 & 2.14 \\
\hline Nor-Bert Calypso Tw & 89 & 54 & 0.65 & 10.39 & 784 & 177 & 0.47 & 0.46 & 3.52 \\
\hline Den-K Marshall L1 Laurin & 243 & 118 & 0.77 & 6.29 & 412 & 154 & 0.50 & 0.51 & 4.83 \\
\hline Robthom Moscow & 99 & 27 & 0.78 & 9.89 & 120 & 40 & 0.43 & 0.45 & 8.99 \\
\hline Delta Paramount & 155 & 75 & 0.66 & 7.88 & 287 & 118 & 0.51 & 0.53 & 5.79 \\
\hline Zandhoeve Alison & 135 & 86 & 0.64 & 8.43 & 96 & 59 & 0.54 & 0.53 & 10.00 \\
\hline Magor Boliva Allen & 111 & 63 & 0.73 & 9.30 & 1,100 & 280 & 0.52 & 0.51 & 2.97 \\
\hline Jenny-Lou Mrshl Toystory & 121 & 56 & 0.74 & 8.92 & 112 & 62 & 0.51 & 0.50 & 9.26 \\
\hline Regancrest Dolman & 168 & 89 & 0.70 & 7.56 & 1,241 & 307 & 0.49 & 0.50 & 2.79 \\
\hline Jocko Besn & 109 & 50 & 0.68 & 9.39 & 274 & 94 & 0.49 & 0.48 & 5.93 \\
\hline Kerndtway Howie & 64 & 23 & 0.75 & 12.26 & 123 & 32 & 0.54 & 0.54 & 8.87 \\
\hline Diamond-Oak Frosty & 53 & 24 & 0.68 & 13.47 & 132 & 40 & 0.42 & 0.43 & 8.55 \\
\hline Rouki & 57 & 29 & 0.74 & 12.98 & 120 & 41 & 0.49 & 0.49 & 8.96 \\
\hline Roumare & 94 & 55 & 0.63 & 10.11 & 65 & 50 & 0.51 & 0.51 & 12.15 \\
\hline Stol Joc & 36 & 12 & 0.78 & 16.37 & 115 & 25 & 0.50 & 0.50 & 9.20 \\
\hline Orcival & 46 & 12 & 0.61 & 14.54 & 108 & 32 & 0.45 & 0.44 & 9.46 \\
\hline Morningview Ashlar & 70 & 34 & 0.80 & 11.72 & 80 & 24 & 0.45 & 0.45 & 10.99 \\
\hline
\end{tabular}

${ }^{(1)} \mathrm{N}$, number of records (first inseminations); h, number of herds; NRR, non-return rate; e, estimation error; pNRR, predicted NRR, which is the logistic model solution, estimated for each Holstein bull, when model parameters were applied to a mean cow (as indicated in Table 1). 
could affect NRR, data suggested a significant role of the sire on this parameter.

The service bull's relative contribution to whether pregnancy will occur is considerable, although apparently low compared to the proportion of the phenotypic variation attributable to the additive genetic effects of the cow. Sires vary in conception rates, and frequent use of sub-fertile bulls affects the herd reproductive performance. The results should be interpreted taking into account that only bulls with satisfactory semen were used for AI; therefore, the present study did not include service bulls with inferior semen quality. In absence of bull fertility evaluations, farmers and technicians are unable to consider male fertility when making breeding decisions.

\section{Conclusions}

1. The reproductive performance in terms of the 56-day non-return rate (56-NRR) is associated with age at insemination, days from previous calving to insemination, milk production level at the time of insemination and herd size.

2. Previous calving difficulty and season of insemination are not significantly related to 56-NRR.

3. The ability to compare estimates of service bull fertility, already adjusted for systematic environmental effects, can be valuable in taking decisions in reproductive programs.

\section{References}

AFRICOR-LUGO. Asociación Provincial de Gandeiros de Lugo para o Control de Rendementos. Memoria 2009. Disponible en: $<$ http://www.africorlugo.com/memoria.asp?id=8>. Accedido el: 1 sept. 2010.

AL NAIB, A.; HANRAHAN, J.P.; LONERGAN, P.; FAIR, S. In vitro assessment of sperm from bulls of high and low field fertility. Theriogenology, v.76, p.161-167, 2011.

ANDERSEN-RANBERG, I.M.; KLEMETSDAL, G.; HERINGSTAD, B.; STEINE, T. Heritabilities, genetic correlations, and genetic change for female fertility and protein yield in Norwegian dairy cattle. Journal of Dairy Science, v.88, p.348-355, 2005.

AVERILL, T.A.; REKAYA, R.; WEIGEL, K. Genetic analysis of male and female fertility using longitudinal binary data. Journal of Dairy Science, v.87, p.3947-3952, 2004.

BASTIN, C.; LOKER, S.; GENGLER, N.; SEWALEM, A.; MIGLIOR, F. Genetic relationships between body condition score and reproduction traits in Canadian Holstein and Ayrshire first-parity cows. Journal of Dairy Science, v.93, p.2215-2228, 2010.

BEN JEMAA, S.; FRITZ, S.; GUILLAUME, F.; DRUET, T.; DENIS, C.; EGGEN, A.; GAUTIER, M. Detection of quantitative trait loci affecting non-return rate in French dairy cattle. Journal of Animal Breeding and Genetics, v.125, p.280-288, 2008.

BERGLUND, B. Genetic improvement of dairy cow reproductive performance. Reproduction in Domestic Animals, v.43, p.89-95, 2008.

BERRY, D.P.; EVANS, R.D.; MCPARLAND, S. Evaluation of bull fertility in dairy and beef cattle using cow field data. Theriogenology, v.75, p.172-181, 2011.

CLAY, J.S.; MCDANIEL, B.T. Computing mating bull fertility from DHI nonreturn data. Journal of Dairy Science, v.84, p.1238-1245, 2001.

EGHBALSAIED, S. Estimation of genetic parameters for 13 female fertility indices in Holstein dairy cows. Tropical Animal Health and Production, v.43, p.811-816, 2011.

JAMROZIK, J.; FATEHI, J.; KISTEMAKER, G.J.; SCHAEFFER, L.R. Estimates of genetic parameters for Canadian Holstein female reproduction traits. Journal of Dairy Science, v.88, p.2199-2208, 2005.

JANSEN, J.; WERF, J. van der; BOER, W. de. Genetic relationships between fertility traits for dairy cows in different parities. Livestock Production Science, v.17, p.337-349, 1987.

LEBLANC, S. Assessing the association of the level of milk production with reproductive performance in dairy cattle. The Journal of Reproduction and Development, v.56, p.1-7, 2010. Supplement.

LÖF, E.; GUSTAFSSON, H.; EMANUELSON, U. Associations between herd characteristics and reproductive efficiency in dairy herds. Journal of Dairy Science, v.90, p.4897-4907, 2007.

MALHI, P.S.; ADAMS, G. P.; MAPLETOFT, R.J.; SINGH, J. Oocyte developmental competence in a bovine model of reproductive aging. Reproduction, v.134, p.233-239, 2007.

MEKONNEN, T.; BEKANA, M.; ABAYNEH, T. Reproductive performance and efficiency of artificial insemination smallholder dairy cows/heifers in and around Arsi-Negelle, Ethiopia. Livestock Research for Rural Development, v.22, p.1-5, 2010.

METEOGALÍCIA. Informes climatológicos. Disponível em: $\quad<$ http://www.meteogalicia.es/observacion/informesclima/ informesIndex.action?request_locale $=\mathrm{es}>$. Acesso em: 1 jun. 2010.

MIGLIOR, F.; PIZZI, F.; GUAITA, N. Effect of environmental factors on non return rate in Italian Holstein-Friesians. Interbull Bulletin, v.27, p.106-108, 1997.

MILLER, R.H.; CLAY, J.S.; NORMAN, H.D. Relationship of somatic cell score with fertility measures. Journal of Dairy Science, v.84, p.2543-2548, 2001.

MORTON, J.M.; TRANTER, W.P.; MAYER, D.G.; JONSSON, N.W. Effects of environmental heat on conception rates in lactating dairy cows: critical periods of exposure. Journal of Dairy Science, v.90, p.2271-2278, 2007. 
NORMAN, H.D.; WRIGHT, J.R.; HUBBARD, S.M.; MILLER, R.M.; HUTCHISON, J.L. Reproductive status of Holstein and Jersey cows in the United States. Journal of Dairy Science, v.92, p.3517-3528, 2009.

PRYCE, J.E.; ROYAL, M.D.; GARNSWORTHY, P.C.; MAO, I.L. Fertility in high-producing dairy cow. Livestock Production Science, v.86, p.125-135, 2004.

PURSLEY, J.R.; SILCOX, R.W.; WILTBANK, M.C. Effect of time of artificial insemination on pregnancy rates, calving rates, pregnancy loss, and gender ratio after synchronization of ovulation in lactating dairy cows. Journal of Dairy Science, v.81, p.2139-2144, 1998.

ROCHA, A.; ROCHA, S.; CAVALHEIRA, J. Reproductive parameters and efficiency of inseminators in dairy farms in Portugal. Reproduction of Domestic Animals, v.36, p.319-324, 2001.

ROTH, Z. Heat stress, the follicle, and its enclosed oocyte: mechanisms and potential strategies to improve fertility in dairy cows. Reproduction of Domestic Animals, v.43, p.238-244, 2008.

SØRENSEN, M.K.; NORBERG, E.; PEDERSEN, J.; CHRISTENSEN, L.G. Invited review: crossbreeding in dairy cattle: a Danish perspective. Journal of Dairy Science, v.91, p.4116-4128, 2008.

SOYDAN, E.; OCAK, N.; ONDER, H. Conception of Jersey cattle in Turkey. Tropical Animal Health and Production, v.41, p.623-628, 2009.

SUN, C.; MADSEN, P.; NIELSSEN, V.S.; ZHANG, Y.; LUND, M.S.; SU, G. Comparison between a sire model and an animal model for genetic evaluation of fertility traits in Danish Holstein population. Journal of Dairy Science, v.92, p.4063-4071, 2009.

TAŞ, M.; BACINOGLU, S.; CIRIT, Ü.; OZGÜMÜŞ, S.; KAŞGÖZ, H.; PABUCCUĞLU, S. Estimation of the potential fertility based upon non-return rates of bulls: using polyacrylamide gel instead of cervical mucus in the sperm penetration test. Theriogenology, v.68, p.981-987, 2007.

VAN DOORMAAL, B.J.; KISTEMAKER, G.J.; MIGLIOR, F. Implementation of reproductive performance genetic evaluations in Canada. Interbull Bulletin, v.37, p.129-133, 2007.

WALL, E.; BROTHERSTONE, S.; WOOLLIAMS, J.A.; BANOS, G.; COFFEY, M.P. Genetic evaluation of fertility using direct and correlated traits. Journal of Dairy Science, v.86, p.4093-4102, 2003.

Received on September 9, 2010 and accepted on May 5, 2011 